\title{
Using Constructivist Teaching Strategies to Enhance Academic Outcomes of Students with Special Needs
}

\author{
Joseph P. Akpan ${ }^{1}$, Lawrence A. Beard ${ }^{2, *}$ \\ ${ }^{1}$ Department of Secondary Education, Jacksonville State University, USA \\ ${ }^{2}$ Curriculum and Instruction, Jacksonville State University, USA
}

Copyright $(\mathcal{C} 2016$ by authors, all rights reserved. Authors agree that this article remains permanently open access under the terms of the Creative Commons Attribution License 4.0 International License

\begin{abstract}
Over the past decades many teaching strategies have been proposed by various educators to improve education of all students including students with special needs. No single one of these proposed teaching strategies meets the needs of all students. The new Every Student Succeeds Act, successor to No Child Left behind Law, which transfers oversight from federal level back to states, could be a benefactor for constructivism and special education. Educators are also optimistic that the new Every Student Succeeds Act will be better for vulnerable students in special education because it will introduce more flexibility in how individual states carry out evaluation of students and teachers. In addition, it will provide more flexibility on testing and adapt the curriculum to student's needs. It would further reduce time and energy for students preparing for standardized tests or statewide exams. It will also end "Adequate Yearly Progress"-a measure that required schools to show test score gains. Constructivist teaching philosophy is all about accepting student autonomy where student thinking drives the lessons, where dialogue, inquiry, and puzzlement are valued and assessing student learning is in the context of teaching. It helps teachers to draw on new ideas as they make decisions about which teaching techniques are most appropriate for all students to learn. Now is the time to revisit the great debate of constructivism versus teacher-centered instruction and special education. Time has come to effectively explore our educational system and examine the core unit of the whole enterprise, the textbook, the classroom, a setting that is often dominated by teacher talk and students listen.
\end{abstract}

Keywords Constructivist Teaching Strategies, Student with Special Needs, Academic Outcomes, Students with Learning Disabilities, Positive Learning, Policy Makers, Indirect Instruction, Every Student Succeeds Act

\section{Introduction}

American politicians, educators and lobbyists have been expressing concern over the education of students with special needs. School officials are calling on states to transform post-secondary educator preparation in order to better serve all learners, including those with special needs. Recently, a bipartisan group of lawmakers voted 85 to 12 to approve large-scale sweeping legislative changes successor to No Child Left behind Law to the Every Student Succeeds Act. These sweeping changes would not only end a controversial federal policy which has governed education for more than a decade, but will become a benefactor for special education and student-centered teaching strategies. This article addresses how the new Every Student Succeeds Act affects special education as well as being a benefactor to student-centered teaching strategies. In addition, this article proposes that the large-scale education changes would benefits constructivism than before. The article furthermore proposes that the sweeping changes will put to an end the "teacher-shoptalk": lessons that are predominantly textbooks oriented the devaluing of all students thinking, tests that drive curriculum testing, and overemphasize curriculum mastery. It is time for the lawmakers to begin to make a difference in how students learn by encouraging student-to-student interaction, initiating lessons that foster cooperative learning, and providing opportunities for students to be exposed to interdisciplinary curriculum. However, students must understand that they are ultimately responsible for their own learning within a learning atmosphere that includes all the aforementioned strategies (Duke, Harper, \& Johnston, 2013[1]; Tracey \& Morrow, 2012[2]; Hashim \& Kasbolah, 2012[3]; Ultanir, 2012[4]; Brown, 2003[5]; Hakverdi-Can, \& Sonmez, 2012[6].

Every student receives and processes information in different ways: Some learn by listening and sharing ideas, some learn by thinking through ideas, some learn by testing theories, some learn by synthesizing content and context, and some learn by reasoning logically and intuitively. Learning disabilities are a group of disorders manifested by difficulties in acquisition and use of listening, speaking, reading, writing, reasoning, mathematical abilities or of social skills (National Institute for Literacy, 2002, p. 2) [7]. These disorders are presumed to exist due to a central nervous system 
dysfunction. Legislators, policy makers, school principals, counselors and post-secondary educators believe that the time has come to reform our current teaching strategy for all students, including students with special needs. The concept of constructivism has extended beyond research and into the American classroom. It has also been the subject of present exploration by academics (Jia, 2010; [8] Bay, Bagceci \& Cetin, 2012 [9]; Brandon \& All, 2010 [10]; Steele, 2005 [11]). One of the most unique and challenging issues that parents, teachers, school administrators, politicians, and philosophers have debated is how to enhance the academic learning experience and opportunities for all students (Steele, 2005 [11]; Brandon \& All, 2010 [10]; Snowman, McCown, \& Biehler, 2009 [12]; Sultan, Woods, \& Koo, 2011 [13]; Ultanir, 2012 [4]; Koh, Chai \& Tsai, 2014[14].

Misconceptions on how students construct knowledge and how teachers should deliver instruction in our nation's schools currently exist. These include lessons dominated by expository methodology in which the teacher is the expert. Using the expository teaching, students are viewed as "blank slate" onto which information is etched by the teacher. The teacher plays videos to wipe away instructional time, assigns meaningless tasks for lessons which are predominantly textbook oriented. Moreover they discredit student thinking, and overemphasize curriculum mastery. These strategies are not helping students construct meaning in the classroom because students are not viewed as thinkers with emerging theories about the world they live. It is time educators begin to make a difference in how students learn by encouraging student-to-student interaction, curricular activities rely heavily on primary sources of data and manipulative materials, initiating lessons that foster cooperative learning, and providing opportunities for students to be exposed to interdisciplinary curriculum. Students would then be responsible for their own learning within an environment that includes all the aforementioned teaching methods.

This article calls for all educators including teachers of students with special needs to begin to make important paradigm shifts in the way they teach and care about students learning. Teachers must abandon the old traditional teaching model in which curriculum is presented part to whole, with emphasis on basic skills. In the constructivist classroom, curriculum is presented whole to part with emphasis on big concepts. These best teaching practices influence and enhance how students think, act, demonstrate, and exhibit knowledge. In the constructivist classroom, simple or complex curricular activities serve to bolster relevance in students and teachers generally behave in an interactive manner, mediating the environment for students learning. Constructivist instructions are practical in nature; focus on real-life applications that might be used to refocus the process of educational reform. This method of instruction suggests new norms, culture of teaching, and structures for classroom practices in the $21^{\text {st }}$ century education.

Furthermore, this article will acquaint educators with the philosophical roots of the constructivist model and enable them with the tool to implement this model in their classrooms. All educators should encourage students to come to class with expectancy and excitement, essentially to learn by doing. Critiques of constructivism think that the model is old wine in the new bottle of education or a weak concept that does not provide students with lifelong learning. This paper asserts that constructivism is new wine in a new bottle; every post-secondary educator must be encouraged to jump on this bandwagon to provide all students with a unique and life-long learning experience. Teachers must come together to understand the idea that knowledge is constructed by individuals differently and is a product of the human mind. All learners need teaching strategies which arouse the unique interest and curiosity to learn. The use of real-life applications and asking stimulating open-ended questions enhance the learning experience for all students. Today, the challenges of teaching a diverse student population are at the forefront of all education initiatives nationwide. The use of constructivist teaching model can help teachers meet some learning challenges of our students with special needs and therefore bridge the achievement gap in the 21 st century. It is the most effective teaching strategy that works well in an inclusive classroom, as learning begins with students understanding of a subject and is developed by participation in the realistic and meaningful learning experiences (Snowman, et., 2009 [12]; Ultanir, 2012 [4]; Koh, Chai \& Tsai, 2014[14]; Hashim \& Kasbolah, 2012[3]; Sultan, Woods, \& Koo, 2011 [13].

\section{Legislative Changes and Special Education}

The current legislative act that revises No Child Left behind Law is a breakthrough to special education and constructivism. The sweeping changes would affect how schools are judged, and would eliminate a deadline for academic proficiency and streamline students' annual testing regime if administered correctly. It can end controversial federal policy that has governed education for decades and restore much control to local districts and schools. The successor to No Child Left behind Act would end the expository methodology view of teaching and learning, which claimed that knowledge, is discovered through the manipulation of objects or acquired from others when learners listen to what teachers say. Now is the time to revisit the long standing debate of constructivism versus teacher-centered instruction for special education. The new Every Student Succeeds Act will be better for vulnerable students in special education because it provides more flexibility on testing. It also ends "Adequate Yearly Progress" a measure that required schools to show test score gains. Preschool development grants for low-income children and an arts education fund are included. Experts claimed that Arts education is more construcvist than practicing for the high stakes test (Koh, Chai \& Tsai, 
2014[14]; Sultan, Woods, \& Koo, 2011 [13].The new Every Student Succeeds Act will stop the practice of putting multiple student subgroups (students with disabilities and low-income students, for example) into "supersubgroup"-a practice that can mask inequities. Every Student Succeeds Act gives schools more local control over curriculum that individual districts will now move toward more constructivist teaching methods versus teaching to the test (Kirp, D. L. 2015[37]. http://topics.nytimes.com/top/referen ce/timestopics/subjects/n/no_child_left_behind_act/index.ht $\mathrm{ml}$

\section{Constructivist Teaching Model}

In very simple terms, people construct their own understandings of the world in which they live. Teachers constantly search for new strategies to help them understand and connect to their past or present experiences. As a function of conventional wisdom, we know that some people are good, some are bad, some are more complex than others, etc. These are all lessons from reflection and interactions with people.

Constructivism is a teaching model not a theory. Essentially, it is a model or metaphor of how people learn or how learning takes place (Von Glasersfeld, 1989 [15]; Cobern, 1995; [16]). It justifies the putting together of new ideas by interpreting new experiences in light of prior knowledge so that the new ideas come to make sense to the learner (Cobern, 1995 [16]). The strengths of constructivism lie in the construction of knowledge and what that means for students and teachers. Since knowledge cannot be transferred from one individual to another like a commodity, the role of the teacher as knowledge giver in the classroom becomes moot. Educators must accept the fact that knowledge is constructed in action and must be constructed by individual knowers; instruction must be student-dominated where teachers function as facilitators. Baker \& Piburn (1997) [17] further claim that knowledge is built in social contexts; pedagogy must encourage student-to-student interactions and collaboration. It is a well-known fact that knowledge construction is strongly influenced by prior experience and learners make sense of the world by synthesizing new experiences into what they have previously come to understand in their daily life (Brooks \& Brooks, 1993; [18] Ultanir, 2012; [4] Steele, 2005 [11]. In other words each learner must construct meaning for oneself and that the only learning that can take place is that which is connected to the individual's already-existing knowledge, experiences, or conceptualizations (Von Glasersfeld, 1989[15]). This implies that learning involves negotiation and interpretation. According to Von Glasersfeld, (1989[15]), what children learn is not a copy of what they observe in their immediate environments but comes from the result of their own thinking, reflection and processing information (Von Glasersfeld, 1989; [15] Steele, 2005; [11]).

A constructivist teaching model suggests that "as we experience something new, we internalize it through our past experience or knowledge constructions we have previously established" (Crowther, 1997, p. 3; [19] Steele, 2005 [11]). The primary job of a teacher is to enable children to think out-of the-box by making their own connections that result in valid internalized meanings unique to them. In this case, the teacher leads the children through exploratory activities that enable them to investigate on their own and come to their own conclusions as to what is happening in the immediate environment (Martin, 2003; [20] Von Glasersfeld, 1989 [15]). Penner (2001) [21] argues that, "learning activities must begin by considering the role of student current knowledge, how knowledge is constructed, and the role of the activities in building knowledge" (p. 3). In other words, individuals construct their own new understandings through the interactions of their existing experiences with whatever they come into contact with, making learning a social activity which engages the teacher as facilitator, mentor, and co-explorer who encourages learners to question, challenge and formulate their own ideas and conclusions (Ultanir, 2012; [4] Brooks \& Brooks, 1993; [18]).

The general consensus among educators is that what a person knows is not a function of detached observation but rather created through interaction with their world view and that knowledge and reality are subjective in nature (Fosnot, 1989; [22] Larson \& Keiper, 2007; [23] Brooks \& Brooks, 1993; [18] Bransfor, Brown \& Cocking, 2000; [24] Snowman, et al., 2009 [12]). A typical constructive classroom environment is tasks oriented and designed to enhance hands-on and minds-on learning for all students similar to those encountered in the real world. This type of learning environment should focus on authentic tasks similar to what people see in every day practice similar to on-the-job experiences that would benefit all students (Cognition and Technology Group at Vanderbilt, 1990; Larson \& Keiper, 2007 [23].

A constructivist teacher would have his or her classroom focus on real life problem solving, problem-based learning (PBL), independent investigation, and the pursuit of personal interests, simulation, discussion collaborative learning, think-pair share, and the utilization of higher-order thinking skills. Research studies in cognition, authentic learning, and student engagement support claims that student-centered teaching is a beneficial teaching strategy for all students, including students with special needs (Brooks \& Brooks, 1993; [18] Larson \& Keiper, 2007 [23].

\section{Evidence Supporting Constructivism}

Learners will be able to control their own learning. Some educators are extremely optimistic that the new Every Student Succeeds Act will open a new door for special education and students with special needs. The power and sanctity of the curriculum and the subordination of students own emerging concepts are profound concerns of constructivism. Many students struggle to understand 
concepts in isolation, to learn parts without seeing wholes, to make connections where they see only disparity, and to accept as reality what their perceptions question. For smart students, success in school has very little to do with true understanding, and much to do with coverage of the curriculum. In most schools, the curriculum is held as absolute, and teachers are not allowed to make changes even when students do not clearly understand important concepts. The current new Every Student Succeeds Act will make sure that teachers are not reticent to adapting the curriculum to students' needs; the school responsibility is to view transcripts of those students who have difficulty understanding the unchanged curriculum as slow or disabled. These students can be removed from the mainstream classes, provide remedial instruction, or differentiate the instruction. In many school districts throughout the nation, students spend a good deal of time preparing for standardized tests or statewide exams. The debate that frames the current Every Student Succeeds Act will end all the helpless testing. We must set standards for our own professional practice and free students from the anti-intellectual training that occurs under the banner of test preparation. The current Every Student Succeeds Act calls on educators, school teachers and education professionals to adopt student-centered teaching strategy and successfully prepare students for their lives by understanding and honoring the dynamics of learning. In addition, education professionals must recognize that for students, schooling must be a time of curiosity, exploration, and inquiry, and memorizing information must be subordinated to learning how to find information to solve real life problems (Brooks, \& Brooks, 1999[18]. Students experiencing difficulty understanding the lesson or who do not comply with directions might need the teacher to make sure directions are clear, concrete, use fewer words, increase wait time for full compliance. Teachers must physically show students directions, ask the students to repeat it by using Say See Do teaching strategy, so that the student knows what is required to do. These are different ways constructivist teachers can help all students understand and increase their full participation and mask inequities in the classroom (Koh, Chai \& Tsai, 2014[14]; Sultan, Woods, \& Koo, 2011 [13]; Von Glasersfeld, Watson (2001) [15]; Battenfeld \& Crowford (2015[39]. http://www.truth-out.org /opinion/item/34080-every-student-Succeeds-act-still-leaves -most-vulnerable-kids-behind

This truth lies at the heart of the constructivist approach to education. This shift in teaching will enable teachers to develop and implement best classroom practices and negotiate the lesson to make sure that students construct knowledge. Individual students will construct meaning differently. Every Student Succeeds Act values all students and encourages learners to control their own learning. This new legislative act is capable of shifting our priorities from ensuring that all students learn the same concepts to ensuring that teachers carefully analyze students' understandings of the concepts to customize their teaching approaches is important step in the new every Student Succeeds education reform Act that will results in increased learning.

Educators must come to realize that knowledge cannot be passed intact from a teacher or book to a learner, nor is it simply discovered in the real world. All students must construct new knowledge for themselves. Instruction guided by the constructivist learning method enhances student engagement learning. This view of knowledge construction in action is called constructivism. In the constructive perspective, new knowledge is always based on the prior or existing knowledge that learners bring to learning situations. Students take in information from many sources, but in building their own knowledge, they connect information to prior knowledge and experiences, organize it, and construct meaning for them. What learners already know influences what they attend to, how they organize input, and how they are able to integrate new constructions to expand their knowledge bases (Brooks, \& Brooks, 1999 [18]. The new Every Student Succeeds Act passed by the U.S. legislations this year is an attempting to improve the civil rights of students with special needs.

All learners are different in many ways. Watts and Pope (1989) [25], emphasized that persons differ from each other in their ways of construction of knowledge; meaning individuals interpret the world around them differently through their own world view rather than being a passive recipient of another individual's knowledge or thinking. The rationales of adopting constructivist model to enhance education of all students are twofold: first, this model allows educators to learn about their own learners, which gives rise to better tailored activities promoting learning by doing (Watts \& Pope, 1989 [25]). Secondly, the learner has the opportunity to think and rethink about their own creativity.

Teachers must enable students to think critically. As a student's ideas change, their knowledge increases. The teacher facilitates this change by interacting with students in positive ways such as asking questions, building appropriate challenges and experiences, and offering new ways of thinking. (Watts \& Pope, 1989 [25]). Steele (2005) [11] states that students with special needs will benefit most from the constructivist model because of their difficulty in adapting from the classroom to more interactive settings according to Snowman, et al., 2009 [12].

Teachers should encourage students to express their problems and then facilitate ways to aid students with solutions to their problems by using what they already know to go beyond what they already think. When educators work with students with special needs, guided discovery learning (GDL) becomes very effective. The goal of GDL is to teach students to be independent problem solvers, to learn the generic steps to scientific inquiry and engage in logical thinking. (McLeskey, Rosenberg \& Westling, 2010 [26]). Von Glasersfeld (1989) [15] "described knowledge as something actively built up from within by a thinking person, and social interactions among students as learners is the core of building knowledge as individuals" (Von Glasersfeld, 1989) [15]. In support of Von Glasersfeld, Watson (2001) 
[15] stated that student learning is a shared social activity, and should be part and parcel of classroom instruction. Furthermore, according to Watson, the constructivist model encourages all students, including special needs to develop a sense of autonomy and initiative they might not otherwise develop in an expository classroom. Educators should encourage students to express their ideas to visualize the relationships between ideas and big concepts, and by doing so, develop problem solving skills. The major responsibility for today's educators should focus on providing a realistic learning environment for their students by modeling, through experimentation, leading questions and scaffolding to elicit student's knowledge.

\section{Evidence against Constructivism}

Several theorists including teachers and administrators have rebelled against constructivism. Some called it propaganda, disastrous fad, teaching strategies with low intellectualism, colorful and jazzy drill and practice ways of instruction (Hayes, 2012[27]; Mayer, 2004[28]; Kirschner et al., 2006[29]; Clements \& Batista, 2009[30]. In addition, some advocates explained failures not because of the methods is at fault, but because these educational methods require a great deal of expertise and have not always been implemented well in actual classroom and this doesn't refute the message, only the implementation (Clements \& Batista, 2009 [30]; Marzano, 2011[31]; Tobias \& Duffy, 2009[32]. Those who argued against constructivist teaching fail to understand it roots and principle. Constructivist methods were simply developed because the nation recognized that our students were not being educated to live in our new information society, this is why the new Every Student Succeeds Act would make sure that our students are educated to their full potential. Constructivist teaching and learning are based on students constructing their own knowledge and understanding through their own activity. By doing so, they can make connections between the new knowledge and previous activity. Those in support of constructivist approach say that students perform higher than those students who were taught using the traditional methods. Also, those students who taught using constructivist methods were able to answer standard procedural questions conceptual questions and critical questions outperform those who were taught using direct instruction (Kain,2003[33]; Boaler, 2001[34]; Kirschner, 2014[29]; Rowman \& Littlefeld, 2015[40]. Retrieved from: http://betrayed-whyed ucationisfailing.blogspot.com/2012/04/has-constructivism-i ncreased-special.html

\section{Recommendations}

This paper makes many recommendations for those who opposed constructivist principle. They should make all efforts to relay the necessary information and then help students make connections to the real world. Since more teachers do not have constructivist backgrounds more teacher extensive training and professional development on how to teach using constructivist methods are needed. Students, parents and teachers are part of the Every Student Succeeds Act. There is no doubt that constructivism has a place in the American classroom as well as absolute flaws and professional development training for teachers and administrators are needed. All educators must be trained on the constructivist teaching methods in order to make Every Student Success Act a success. A balanced approach to these recommendations is to put the student first. Teachers must make sure that students are taught necessary skills, more problem-based instructions and how to help students build on prior knowledge. Administrators must equally make funding available to train teachers across all school districts and encourage the support of non-teaching staff to make constructivist teaching a reality, no matter one's opinion on constructivism.

For those students with neurological-based behavior (NBB), such as Learning Disability (LD), Attention-Deficit Hyperactivity Disorder (ADHA), Sensory Integration Dysfunction (SID), Bipolar Disorder (BD), Fetal Alcohol Spectrum Disorder (FAS), etc., in which the brain's informational processing capability has been compromised, teachers must remain positive. Positive attitudes can greatly improve the quality of service a teacher provides to students with NBB and their families. Teachers must use fewer words and tell students what to do to fix mistakes. Stand close to the students and congratulate them when they begin to comply. The shifting of interaction maybe difficult for NBB students, and Rees and Skimore (2008[35] found acquired brain injury students could Succeeds at one task while ignoring another; they could also Succeeds at completing a task, but would not understand why or contribute to their learning in terms of building concepts. Educators dealing with these students must comply with them by making directions clear, provide concrete, and consistent feedback. Using fewer words, increasing wait time for compliance, physically showing directions, and asking the student to repeat the directions and show the teacher what they are required to do. These are ways teachers can help students with NBB increase their participation in the classroom and enjoy school (Watson, 2001[36]; U. S. Congress. (1988 [38].

\section{Conclusions}

In summary, constructivism is a model of how students learn and how learning takes place. The student is always active when learning takes place. The central focus is that knowledge is constructed by individual knower's; therefore, instruction must be student centered. In addition, knowledge is built in social contexts; pedagogy must encourage student-to-student interactions. Furthermore, knowledge construction is strongly influenced by prior experience; students must be treated as individuals. No one's knowledge 
is an accurate reflection of reality; there is room always for discussion and critical thinking. Many promising proposals have been put forth in the past decades to address the issues surrounding students' construction of knowledge. Not a single proposal met all student needs. While these are good intentions, these proposals don't quite go deep enough to help all students construct knowledge. It promotes learning through experience in an environment that involves the "real world" and offers meaningful, personally interesting challenges. Moreover it requires active learning, provides opportunities to solve real world problems, answer real questions, address real needs, offers the student an opportunity to perform as a expert or professional in their chosen field. Approaching instruction from the constructivist continuum reaches a broader range of students and increases comprehension and self-confidence in all students, teaching students to think for themselves, ask questions and seek answers. The usage of multiple approaches and perspectives when problem solving are vital to the success of all students in American classrooms.

\section{REFERENCES}

[1] Duke, B., Harper, G., \& Johnston, M. (2013). Constructivism as a digital age learning theory. The International HETL Review, Special Issue, 4-13.

[2] Tracy, D. H., \& Morrow, L. M.(2012). Lenses on reading: an introduction to theories and models. New York: The Guilford Press.

[3] Hashim, M., \& Kasbolah, M. (2012). Application of Needham's five phase constructivism model in (civil, electrical and mechanical) engineering subject at technical secondary school. Journal of Education and Learning, 1(1), Retrieved from Questia.

[4] Ultanir, E. (2012). An epistemological glance at the constructivist approach: constructivist learning in Dewy, Piaget, and Montessori. International Journal of Instruction, 5(2), 195-212.

[5] Brown, K. L. (2003). From teacher-centered to learning-centered curriculum: improving learning in diverse classrooms. New York, NY: Routledge.

[6] Hakverdi-Can, M. \& Sonmez, D. (2012). Learning how to design a technology supported inquiry-based learning environment. Science Education International, 23(4), 338-356.

[7] National Institute for Literacy (NIFL). (2002). Adults with learning disabilities: definitions and issues. Retrieved September 7, 2015, from http://www.nifl.gov/nifl/id/archive/definition.htm.

[8] Jia, Q. (2010). A brief study on the implication of constructivist teaching theory on classroom teaching reform in basic education, 3(2), 197-199.

[9] Bay, E., Bageeci, B., \& Cetin, B. (2012). The effects of social constructivist approach on the learners problem solving and metacognitive levels. Journal of Social Science, 8(3), 343-348.

[10] Brandon, A. F., \& All, A. C. (2010). Constructivism theory analysis and application to curricula. Nursing Education Perspectives, 31(2), 89.

[11] Steele, M. M. (2005). Teaching students with learning disabilities: Constructivism or behaviorism? Current Issues in Education [Electronic-version] 8(10). Available: http://cie.ed.asu.edu/volume8/number10/.

[12] Snowman, J., McCown, R., Biehler, R. (2009). Psychology applied to teaching $\left(12^{\text {th }}\right.$ ed.). Boston: Houghton Mifflin.

[13] Sultan, W. H., Woods, P. C., \& Koo, A.(2011). A constructivist approach for digital learning: Malaysian school case study. Educational Technology \& Society, 14(4), 149-150.

[14] Koh, J. H., Chai, C. S., \& Tsai, C. (2014). Demographic factors, TPACK constructs, and teachers perceptions of constructivist-Oriented TPACK. Educational Technology \& Society, 17(1), 186. Retrieved from Questia.

[15] Von Glasersfeld, E. (1989). Cognition, construction of knowledge, and teaching. Synthese, 80, 121-140.

[16] Cobern, W. (1995). Constructivism for science teachers, 6(3). Science Education International, 6(3).

[17] Baker, D., \& Piburn, M. (1997). Constructing science in middle and secondary classrooms. Boston, MA: Allyn \& Bacon.

[18] Brooks, J. G., \& Brooks, M. G. (1999). In search of understanding: the case for constructivist classrooms. Alexandria, VA: Association for Supervision and Curriculum Development.

[19] Crowther, D. T. (1997). The constructivist zone: Editorial. Electronic Journal of Science Education, 2(2). http://unr.edu/homepage/jcannon/ejse/ejsev2n2ed.html.

[20] Martin, D. J. (2003). Elementary science Methods: A constructivist Approach 3nd ed.). Boston, MA: Pearson Education, Allyn \& Bacon.

[21] Penner, D. E. (2001). Cognition, computers, and synthetic science: Building knowledge and meaning through modeling. Review of Research in Education, 25(2000-2001), 1-35.

[22] Fosnot, C. T. (1989). Inquiring teachers, enquiring learners. New York: Teachers College Press. ...

[23] Larson, B. E., \& Keiper, T. A. (2007). Instructional strategies for middle and high school. Taylor \& Francis Group: Oxon OX 144RN.

[24] Branford, J. D., Brown, A. L., \& Cocking, R. R. (Eds.). (2000). How people learn: Brain, mind, experience, and school. Washington, DC: National Academy Press.

[25] Watts, M., Pope, M. (1989). Thinking about thinking, learning about learning: Constructivism in physics education. Physics Education, [Electronic version] 24(6), 326-331. Retrieved June 16, 2015 from Electronic Journal Center.

[26] McLesky, J., Rosenberg, M. \& Westling, D. (2012). Inclusion: Effective Practices for All Students (2nd Ed). Old Tappan, NJ: Pearson, 2012. 
[27] Hayes, N. (2012). Has constructivism increased special-education enrollment in public schools? Retrieved from www.

http://betrayed-whyeducationisfailing.blogspot.com/12/28/2 015 .

[28] Mayer, R. E., (2004). Should there be a three-strike rule against pure discovery learning? American Psychologist, 59(1), 13-20.

[29] Kirschner, P. A. \& Sweller, J., \& Clark, R. E. (2006). Why minimal guidance during instruction does not work: An analysis of the failure of constructivist, discovery, problem-based, experiential, and inquiry-based teaching. Educational Psychologist, 41(2), 75-78.

[30] Clements, D. H. \& Battista, M. T. (1990). Constructivist learning and teaching. Arithmetic Teacher, 38(1), 34-35.

[31] Marzo, R. J. (2011). Art and science of teaching: The perils and promises of discovery learning. Educational Leadership, 86-87.

[32] Tobias, S. \& Duffy, M. D. (2009). Constructivist instruction: Success or failure? New York, NY: Routledge.

[33] Kain, D. (2003). Teacher-centered versus student-centered: Balancing constraint and theory in the composition classroom. Pedagogy 3(1), 104-108.

[34] Boaler, J. (2001).Mathematical modeling and new theories of learning. Teaching Mathematics and its Applications, 20(3),
$121-128$.

[35] Rees, S., \& Skidmore, D. (2008). The classical classroom: Enhancing Learning for Pupils with Acquired Brain Injury (ABI). Journal of Research in Special Educational Needs, 8(2) 88-95.

[36] Watson, J. (2001). Social constructivism: Social constructivism in the classroom. Support for learning, [Electronic-version] 16(3), 140-147. Retrieved June 16, 2015 from Electronic Journal Center.

[37] Kirp, D. L. (2015). No Child Left Behind Retrieved from: The New York Time: http://topics.nytimes.com/top/reference/tim estopics/subjects/n/no_child_left_behind_act/index.html 30 December, 2015

[38] U. S. Congress.(1988). U. S. Congress, Pub. L. No. 100-407. Individuals with Disabilities Education Improvement Act 2004.

[39] Battenfeld \& Crowford (2015).Why public education id failing. Retrieved from: http://www.truth-out.org/opinion/item/34080-every-studentSucceeds-act-still-leaves-most-vulnerable-kids-behind $\quad 30$ December 2015.

[40] Rowman \& Littlefeld, 2015[39]. Why public education is failing. Retrieved from: http://betrayed-whyeducationisfailin g.blogspot.com/2012/04/has-constructivism-increased-specia 1.html. 30 December 2015. 